\title{
Front Matter: Volume 10905
}

, "Front Matter: Volume 10905," Proc. SPIE 10905, Laser Applications in Microelectronic and Optoelectronic Manufacturing (LAMOM) XXIV, 1090501 (23 May 2019); doi: 10.1117/12.2531402

SPIE. Event: SPIE LASE, 2019, San Francisco, California, United States 


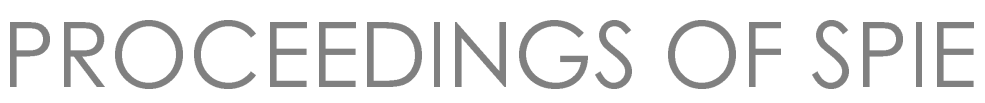

\title{
Laser Applications in Microelectronic and Optoelectronic Manufacturing (LAMOM) XXIV
}

\author{
Tetsuya Makimura \\ Gediminas Račiukaitis \\ Carlos Molpeceres \\ Editors
}

4-6 February 2019

San Francisco, California, United States

Sponsored by

SPIE

Cosponsored by

Okamoto Optics Works (Japan)

Plymouth Grating Laboratory (United States)

Published by

SPIE 
The papers in this volume were part of the technical conference cited on the cover and title page. Papers were selected and subject to review by the editors and conference program committee. Some conference presentations may not be available for publication. Additional papers and presentation recordings may be available online in the SPIE Digital Library at SPIEDigitalLibrary.org.

The papers reflect the work and thoughts of the authors and are published herein as submitted. The publisher is not responsible for the validity of the information or for any outcomes resulting from reliance thereon.

Please use the following format to cite material from these proceedings:

Author(s), "Title of Paper," in Laser Applications in Microelectronic and Optoelectronic Manufacturing (LAMOM) XXIV, edited by Tetsuya Makimura, Gediminas Račiukaitis, Carlos Molpeceres, Proceedings of SPIE Vol. 10905 (SPIE, Bellingham, WA, 2019) Seven-digit Article CID Number.

ISSN: 0277-786X

ISSN: 1996-756X (electronic)

ISBN: 9781510624528

ISBN: 9781510624535 (electronic)

Published by

SPIE

P.O. Box 10, Bellingham, Washington 98227-0010 USA

Telephone +1 3606763290 (Pacific Time) · Fax +1 3606471445

SPIE.org

Copyright @ 2019, Society of Photo-Optical Instrumentation Engineers.

Copying of material in this book for internal or personal use, or for the internal or personal use of specific clients, beyond the fair use provisions granted by the U.S. Copyright Law is authorized by SPIE subject to payment of copying fees. The Transactional Reporting Service base fee for this volume is $\$ 18.00$ per article (or portion thereof), which should be paid directly to the Copyright Clearance Center (CCC), 222 Rosewood Drive, Danvers, MA 01923. Payment may also be made electronically through CCC Online at copyright.com. Other copying for republication, resale, advertising or promotion, or any form of systematic or multiple reproduction of any material in this book is prohibited except with permission in writing from the publisher. The CCC fee code is 0277$786 \mathrm{X} / 19 / \$ 18.00$.

Printed in the United States of America by Curran Associates, Inc., under license from SPIE.

Publication of record for individual papers is online in the SPIE Digital Library.

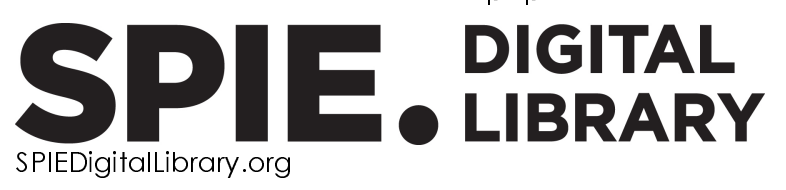

Paper Numbering: Proceedings of SPIE follow an e-First publication model. A unique citation identifier (CID) number is assigned to each article at the time of publication. Utilization of CIDs allows articles to be fully citable as soon as they are published online, and connects the same identifier to all online and print versions of the publication. SPIE uses a seven-digit CID article numbering system structured as follows:

- The first five digits correspond to the SPIE volume number.

- The last two digits indicate publication order within the volume using a Base 36 numbering system employing both numerals and letters. These two-number sets start with 00, 01, 02, 03, 04, 05, 06, 07, 08, 09, OA, OB ... 0Z, followed by 10-1Z, 20-2Z, etc. The CID Number appears on each page of the manuscript. 


\title{
Contents
}

\author{
$\checkmark \quad$ Authors \\ vii Conference Committee
}

FRONTIER IN LASER MICROMACHINING

10905 OD Laser grooving of multi stack material modeling: implementation of a high accuracy tool for laser-grooving and dicing application [10905-12]

10905 OE Modifications of surface topography by acoustic resonance induced by laser ablation with ultrashort laser pulses [10905-13]

10905 OF Selective etching of ultrafast laser modified sapphire [10905-14]

$10905 \mathrm{OH} \quad$ Fused silica ablation by double femtosecond laser pulses with variable delays [10905-16]

$1090501 \quad$ Ultrafast lasers for advanced manufacturing of flat panel displays [10905-17]

LASER-INDUCED FORWARD TRANSFER

10905 OK Reusable laser-absorbing layers for LIFT [10905-19]

10905 OM Laser-Induced Forward Transfer of silver-based pastes for metallization of photovoltaic devices [10905-21]

FUNDAMENTAL ASPECTS OF LASER-MATERIALS INTERACTION I

1090500 Study of plasma formation in solid dielectrics with the help of low-order harmonic emission (Invited Paper) [10905-23]

MATERIALS SYNTHESIS AND FABRICATION I

10905 OX Laser induced crystal defects in monocrystalline silicon [10905-32]

$10905 \mathrm{OZ} \quad$ Low-temperature, high-concentration laser doping of $\mathbf{4 H}-\mathbf{S i C}$ for low contact resistance [10905-34] 
MATERIALS SYNTHESIS AND FABRICATION II

1090512 Direct writing of Cu-based flexible thermal detectors using femtosecond laser-induced reduction (Invited Paper) [10905-37]

NANOSCALE PROCESSING

$1090514 \quad$ Focused laser spike (FLaSk) thermocapillary patterning of micro/nanostructures (Invited Paper) [10905-39]

POSTER SESSION

$1090519 \quad$ Strain sensing using electrically conductive structures composed of $\boldsymbol{\beta}$-SiC fabricated by femtosecond laser direct modification of PDMS (Best Student Poster Award) [10905-43]

10905 1C Development of soft x-ray laser irradiation beamline for ablation and damage study [10905-46] 


\section{Authors}

Numbers in the index correspond to the last two digits of the seven-digit citation identifier (CID) article numbering system used in Proceedings of SPIE. The first five digits reflect the volume number. Base 36 numbering is employed for the last two digits and indicates the order of articles within the volume. Numbers start with 00, 01, 02, 03, 04, 05, 06, 07, 08, 09, OA, OB...0Z, followed by 10-12, 20-2Z, etc.

Ametowobla, Mawuli, OE, OX

Asano, T., OZ

Auyeung, Raymond C. Y., OK

Bovatsek, Jim, Ol

Canteli, David, OM

Chacon, O., OD

Charipar, Kristin M., OK

Charipar, Nicholas A., OK

De Jesús-Villanueva, Nérida H., OK

Díaz-Rivera, Rubén E., OK

Dinh, Thanh-Hung, 1C

Drouin, D., OD

Duchateau, Guillaume, $\mathrm{OH}$

Fennel, Thomas, 00

Flamm, D., OF

Gaudfrin, Kévin, $\mathrm{OH}$

Gómez-Fontela, Miguel, OM

Guzman-Pichardo, Jennifer, 14

Hasegawa, Noboru, 1C

Hatayama, Masatoshi, 1C

Hayashi, Shuichiro, 19

Higashiguchi, Takeshi, 1C

Hinderberger, S., OX

Hollister, Terence, 0

Husakou, Anton, 00

Ichimaru, Satoshi, 1C

Ikeda, A., OZ

Ikenove, $\mathrm{H} ., \mathrm{OZ}$

Imokawa, K., $\mathrm{OZ}$

Ishino, Masahiko, 1C

Ivanov, Mikhail, 00

Jenne, M., OF

Jitianu, Andrei, 14

Jürgens, Peter, 00

Kaiser, M., OF

Kikuchi, T., OZ

Klein, Lisa C., 14

Kleiner, J., OF

Kling, Rainer, $\mathrm{OH}$

Köhler, J. R., OX

Kroschel, Alexander, $\mathrm{OE}$

Kruse, Björn, 00

Kumkar, M., OF

Kunz, Gerhard, OE

Lanoy, F., OX

Lauzurica, Sara, OM

Leute, R., OF

Liewehr, Benjamin, 00

Lopez, John, $\mathrm{OH}$
Ma, Tianxing, 14

Márquez, Andrés, OM

Menold, Tobias, OE, OX

Mermillod-Blondin, Alexandre, 00

Michalowski, Andreas, $\mathrm{OE}$

Mishchik, Konstantin, $\mathrm{OH}$

Mizoshiri, Mizue, 12

Molpeceres, Carlos, OM

Morales, Miguel, OM

Moreno, Juan José, OM

Moussodji, J., OD

Munoz-Martin, David, OM

Nakajima, Yasutaka, 19

Nakamura, D., $\mathrm{OZ}$

Nishikino, Masaharu, 1C

Ohmer, K., OX

Peltz, Christian, 00

Piqué, Alberto, OK

Priester, R., OF

Sakaue, Kazuyuki, 1C

Santerre, F., OD

Schmauch, J., OF

Singer, Jonathan P., 14

Terakawa, Mitsuhiro, 19

Vrakking, Marc J. J., $0 O$

Washio, Masakazu, $1 \mathrm{C}$

Werner, J. H., OX

Witting, Tobias, 00

Zimmermann, F., OF 
Proc. of SPIE Vol. 10905 1090501-6

Downloaded From: https://www.spiedigitallibrary.org/conference-proceedings-of-spie on 26 Apr 2023 Terms of Use: https://www.spiedigitallibrary.org/terms-of-use 


\section{Conference Committee}

Symposium Chairs

Beat Neuenschwander, Berner Fachhochschule Technik und Informatik (Switzerland)

Xianfan Xu, Purdue University (United States)

Symposium Co-chairs

Koji Sugioka, RIKEN Center for Advanced Photonics (Japan)

Reinhart Poprawe, Fraunhofer-Institut für Lasertechnik (Germany)

Program Track Chairs

Henry Helvajian, The Aerospace Corporation (United States)

Guido Hennig, Daetwyler Graphics AG (Switzerland)

Conference Chairs

Tetsuya Makimura, University of Tsukuba (Japan)

Gediminas Račiukaitis, Center for Physical Sciences and Technology (Lithuania)

Carlos Molpeceres, Universidad Politécnica de Madrid (Spain)

Conference Program Committee

Craig B. Arnold, Princeton University (United States)

Jan J. Dubowski, Université de Sherbrooke (Canada)

Costas P. Grigoropoulos, University of California, Berkeley (United States)

Bo Gu, Bos Photonics (United States)

Henry Helvajian, The Aerospace Corporation (United States)

Guido Hennig, Daetwyler Graphics AG (Switzerland)

Heinz P. Huber, Hochschule für Angewandte Wissenschaften München (Germany)

Michel Meunier, Ecole Polytechnique de Montréal (Canada)

Yoshiki Nakata, Osaka University (Japan)

Beat Neuenschwander, Berner Fachhochschule Technik und Informatik (Switzerland)

Hiroyuki Niino, National Institute of Advanced Industrial Science and Technology (Japan)

Alberto Piqué, U.S. Naval Research Laboratory (United States)

Jie Qiao, Rochester Institute of Technology (United States)

Andrei V. Rode, The Australian National University (Australia)

Stephan Roth, BLZ Bayerisches Laserzentrum GmbH (Germany) 
Klaus Sokolowski-Tinten, Universität Duisburg-Essen (Germany)

Razvan Stoian, Laboratoire Hubert Curien (France)

Koji Sugioka, RIKEN (Japan)

Xianfan Xu, Purdue University (United States)

Steven M. Yalisove, University of Michigan (United States)

Session Chairs

1 Laser Processing Based on Pulse Width and Pulse Train Arrangement Techniques

Gediminas Račiukaitis, Center for Physical Sciences and Technology (Lithuania)

2 Direct Writing

Craig B. Arnold, Princeton University (United States)

3 Laser Processing Based on Beam Shaping Techniques

Cormac McDonnell, Hochschule für Angewandte Wissenschaften München (Germany)

$4 \quad$ Frontier in Laser Micromachining

Andrei V. Rode, The Australian National University (Australia)

5 Laser-Induced Fonward Transfer

Jie Qiao, Rochester Institute of Technology (United States)

6 Fundamental Aspects of Laser-Materials Interaction I

Beat Neuenschwander, Berner Fachhochschule Technik und Informatik (Switzerland)

7 Fundamental Aspects of Laser-Materials Interaction II

Carlos Molpeceres, Universidad Politécnica de Madrid (Spain)

8 Materials Synthesis and Fabrication I

Carlos Molpeceres, Universidad Politécnica de Madrid (Spain)

9 Materials Synthesis and Fabrication II

Yoshiki Nakata, Osaka University (Japan)

10 Nanoscale Processing

Gediminas Račiukaitis, Center for Physical Sciences and Technology (Lithuania) 